\section{Do fingimento à imaginação moral: diálogos entre história e literatura}

\author{
Júlio Pimentel Pinto [*]
}

[*] Universidade de São Paulo (USP), Programa de Pós-Graduação em História Social, São Paulo (SP), Brasil. juliop@uol.com.br

ORCID: http://orcid.org/0000-0002-4617-9910
Resumo: O texto explora as relações entre história e ficção, a partir de registros da historiografia, da ficção e da teoria e crítica literárias, buscando encontrar convergências e definir limites, problemas e possibilidades de diálogo entre as duas formas narrativas. Recorre, para tanto, a três eixos analíticos: o lugar do leitor e da leitura; a leitura historiográfica da ficção; a relação entre verdade e mentira; as dimensões cognitivas do estranhamento e do deslocamento.

Palavras-chave: História; Ficção; Narrativa.

\section{From pretence to moral imagination: dialogues between history and literature}

Abstract: The text explores the relations between history and fiction, from the records of historiography, fiction and literary theory and criticism, trying to find convergences and define limits, problems and possibilities of dialogue between the two narrative forms. To develop the argument, the text analyses the place of the reader and the reading; the historiographical rea ding of fiction; the relationship between truth and lies; the cognitive dimensions of estrangement and displacement.

Keywords: History; Fiction; Narrative. 
Bueno, la literatura no refleja nada.

Ricardo Piglia

I.

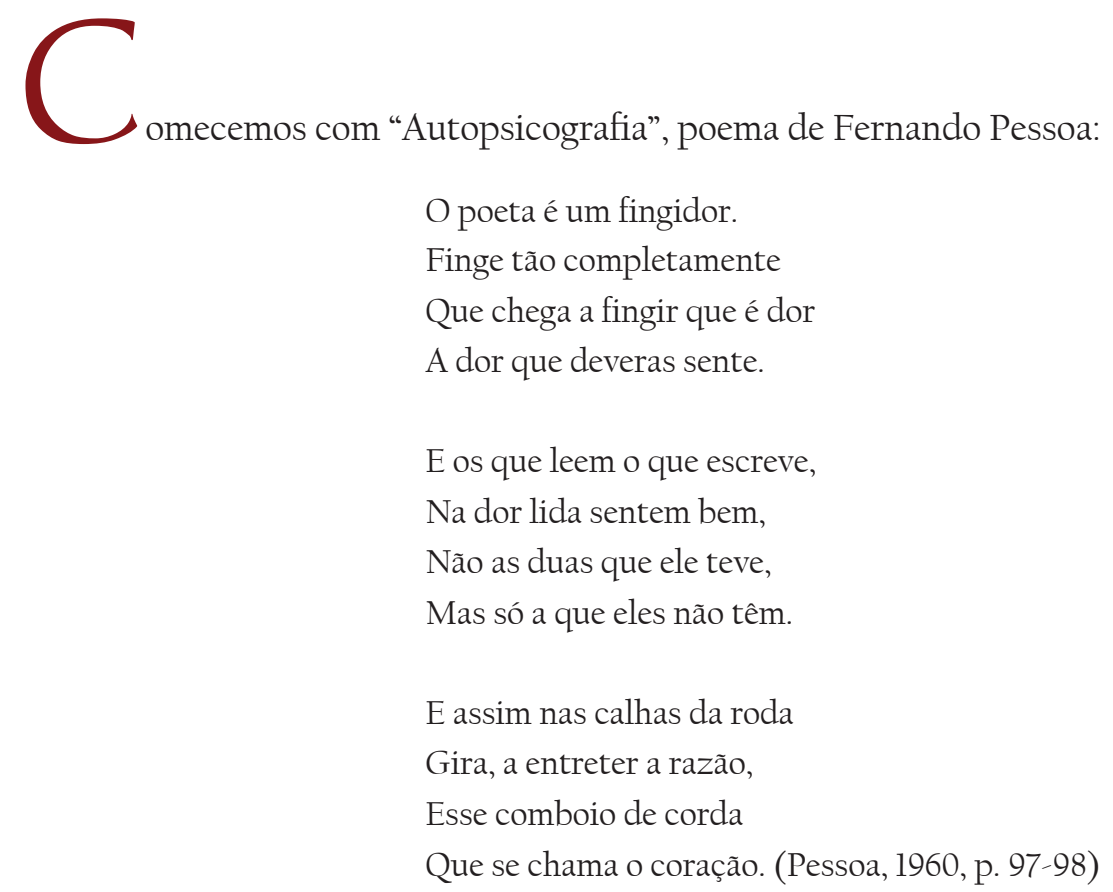

O poema é bastante conhecido e citado, ocasionalmente banalizado e, talvez por tê-lo ouvido tantas vezes, raramente paramos para lê-lo com calma, pelo menos naquilo que nos interessa imediatamente: os vários lugares e as várias posições de quem se relaciona com um texto.

Há dois personagens no poema: aquele que escreve ("o poeta") e aquele que lê, significativamente tratado no plural: "os que leem". Cada um desses personagens, por sua vez, realiza dois movimentos distintos.

O primeiro deles, aquele que escreve, "deveras sente uma dor", mas a dor que ele escreve (chamemos de "a dor escrita") é diferente da dor que ele sente (a "dor sentida"): é um fingimento; ou seja, a experiência vivida, ao se tornar escritura, transforma-se, e essa transformação é fundamental porque é ela que define este personagem: ele é um escritor - poeta —e, portanto, é um fingidor. Em outras palavras, escrever e fingir confinam-se, e a passagem 
do vivido para o representado (ou o encontro, ou a tensão entre eles), a passagem da "dor sentida" para a "dor escrita", é o que caracteriza o poeta.

O segundo personagem é aquele que lê o que o primeiro escreveu. Esse leitor também "sente uma dor"; sua dor, porém, é diferente daquela que o poeta sentiu (e não expressou, logo, é inacessível ao leitor) e é diferente daquela que o poeta não sentiu, mas, fingindo, expressou; ou seja, o leitor, ao se confrontar com o texto, sente outra dor, uma terceira dor, estranha tanto à dor vivida pelo escritor, quanto à dor por ele representada. Essa terceira dor resulta da transposição, pelo leitor, daquilo que lê para sua experiência pessoal - numa espécie de caminho de volta do representado para o vivido, embora outro vivido, por outra pessoa, em outro tempo e lugar. O leitor considera a representação feita pelo poeta como parte do mundo, marca de uma experiência talvez vivida, mas alheia, e dela se apropria, metamorfoseando-a. Em outras palavras, ele lê "de fora" e altera, continua, desenvolve.

Essa segunda estrofe, que fala dos leitores, funciona como antítese da primeira estrofe, que trata do escritor. E a terceira estrofe propõe então uma espécie de síntese. Nela, o narrador localiza mais uma diferença ou tensão, que ajuda a compreender as duas tensões anteriores, a da razão/irrazão: é o "comboio de corda" que "gira a entreter a razão" num movimento de aproximação e distanciamento entre experiência e escrita, entre leitura e experiência. Da vida, passa-se ao texto, do texto volta-se à vida, mas a outra vida.

Recorro ao poema para introduzir nossa discussão e reconhecer que: 1) o poema trata de três dores (a sentida, a escrita e a lida), essas dores diferem entre si e realizam um movimento regular em que texto e vida, representação e leitura, cumprem seus papéis; 2) o trabalho de escrita é uma experiência de referência ao real e, simultaneamente, de distanciamento em relação a ele; 3) o trabalho de leitura é uma tentativa de reaproximação do real, mas essa reaproximação é sempre mediada e sempre relativa, inclusive porque a leitura jamais é una, jamais é fixa.

A partir dessas constatações, é preciso analisar as muitas posições do leitor e a inevitável instabilidade da leitura; em seguida, refletir sobre os vínculos entre escrita e representação do real. O objetivo é alcançar o tema central: a relação entre ficção e história que, de forma direta ou indireta, mobilizou e mobiliza historiadores - para citar alguns, Lucien Febvre, Jacques Le Goff, Hayden White, Carlo Ginzburg, Dominick La Capra, David Lowenthal, Jacques Rancière, Georges Didi-Huberman; aqui no Brasil envolveu, entre outros, Nicolau Sevcenko e Maria Stella Bresciani, que, no decorrer dos anos 1980, mostraram, por caminhos diversos e necessários, que a historiografia não poderia ignorar a literatura. 
II.

Em 1979, Italo Calvino publicou Se um viajante numa noite de inverno. O livro conta a história de um protagonista - nomeado "o Leitor" - , que inicia a leitura de um romance e, no momento mais interessante, descobre que o exemplar tem páginas repetidas. Ele volta à livraria, onde conhece "a Leitora", que enfrenta problema semelhante. Começa aí uma espiral de histórias: o livro que eles leem, conforme varia o exemplar, vai mudando de autor, de língua, de trama. Ao ler um livro, na realidade leem muitos livros distintos, numa espécie de quebra-cabeça livresco, em que as histórias se cruzam, misturam-se, combinam-se. O Leitor e a Leitora são levados a criar finais para cada uma das histórias que ficam em aberto: as leitoras e os leitores assumem parte da criação e seu papel, então, se torna explicitamente ativo. Para Calvino (1995, p. 10), "a ação da leitura se torna decisiva; cabe ao leitor o papel de fazer com que a literatura explique sua força crítica e isto pode ocorrer independentemente da intenção do autor". ${ }^{1}$

No mesmo ano, 1979, Umberto Eco publicou Lector in fabula (Eco, 2011). Foi uma coincidência: Calvino e Eco, embora amigos, não sabiam o que outro escrevia, e os dois livros saíram quase simultaneamente. O título do livro de Eco soa um pouco enigmático para o leitor não italiano, porque é um trocadilho quase intraduzível: a expressão "lupus in fabula...", para os italianos, é equivalente ao nosso "falou no diabo...": indica a presença ou a aparição imediata daquele de quem há pouco se falava; Eco trocou lupus por lector - talvez uma tradução para o português fosse "falou no leitor..." - , colocando a leitura no centro das atenções e reiterando um de seus temas principais: o de que todo texto está na iminência de uma nova leitura e de outra interpretação.

O livro de Eco trata de assunto bastante parecido ao do livro de Calvino: qual é o lugar e qual é o papel do leitor? Quais são as possibilidades e os limites da interpretação? Como um texto, no momento da leitura, continua a abrir-se a novos repertórios e leva o leitor a alcançar graus diversos de compreensão? Como o leitor preenche os "espaços em branco" de um livro e insere nesses interstícios elementos que não são ditos? Como o leitor atualiza um texto, realocando-o, ressituando-o no tempo presente da leitura? E podemos prolongar a reflexão para o universo da história e dos historiadores: de que maneira lemos? Como lidamos com os diálogos e descompassos entre temporalidades? Quantas vezes lemos o passado com palavras, conceitos, tratamentos sintáticos e semânticos que não são os daquele passado que estudamos? Quantas vezes, ao nos depararmos com narrativas do passado que comportam aparentes incompatibilidades conceituais ou terminológicas, recorremos à acusação de anacronismo? Quantas vezes a referência ou a manifestação do presente, interpos-

' Em todas as citações em línguas estrangeiras a tradução é livre. 
ta a outras temporalidades, é o caminho possível para preencher, na leitura e na narrativa, os "espaços em branco" do passado? Não por acaso, a discussão acerca do anacronismo ocupou várias páginas de um historiador tão decisivo como Lucien Febvre; foi justamente diante de um estudo literário sobre Rabelais (Lefranc, 1938) que Febvre disparou algumas de suas mais divertidas e conhecidas ironias (Febvre, 2009, p. 153-155). Embora aqui o tema, ou o risco, do anacronismo seja apenas um exemplo da presença ativa do leitor, na historiografia e no pensamento do século XX ele moveu escritos e autores fundamentais: Marc Bloch (1994), Fernand Braudel (1978), Paul Riccur (1968) e tantos outros. No debate do século XXI, a discussão persiste viva, por exemplo, em Jacques Rancière - que afirma que "é a própria ideia do anacronismo como um erro em relação ao tempo que precisa ser desconstruída" (Rancière, 1996, p. 53) —, Nicole Loraux (1993) e Julio Premat (2018) ou em Georges Didi-Huberman, que em alguns de seus escritos realiza uma vigorosa defesa do anacronismo, chegando, inclusive, a constatar sua necessidade e inevitabilidade:

Este é o paradoxo: dizemos que fazer história é não cometer anacronismos; mas também dizemos que só é possível voltar ao passado com o presente de nossos atos de conhecimento. Reconhecemos, então, que fazer história é cometer pelo menos um anacronismo. (...) O anacronismo não é a única maneira possível de dar conta, no saber histórico, dos anacronismos da história real? (Didi-Huberman, 2000, p. 31, 33).

Essa preocupação com uma leitura ativa e (re)criadora, possivelmente anacrônica, não nasceu com Calvino ou Eco e já estava presente em pelo menos dois autores que ambos escritores italianos adoravam: Pessoa e Borges; a "Autopsicografia”, como vimos, é exemplo claro. Em Borges, a discussão aparece, entre outras passagens, no que talvez seja seu texto mais conhecido: um ensaio falso dos anos 1940 que trata de um escritor - Pierre Menard — que resolveu escrever o Quixote em pleno século XX; não outro Quixote ou uma versão do Quixote, mas o Quixote, linha a linha, palavra a palavra igual ao de Cervantes. Sua dificuldade, porém, era imensa: o que significa, para um autor do século XX, reproduzir os termos de um livro do início do século XVII (1605)? Menard — explica Borges — esforçou-se: aprendeu bem o espanhol, recuperou a fé católica, tentou guerrear contra os mouros e esquecer a história da Europa posterior a 1605: ele queria ser Cervantes e, para tanto, era necessário esquecer o futuro do passado. Mas seu trabalho era complexo demais: imaginem, Borges prossegue, um sujeito, em pleno século XX, afirmar, tal qual se faz no Quixote de Cervantes, que a história é "a Mãe da Verdade"? Para Cervantes, no XVII, a frase era um elogio retórico da história; para Menard, no XX, seria a constatação de que a história é a origem, é a mãe do que aconteceu, a explicação e o motivo de tudo, a razão irreversível, e sua verdade impõe-se como absoluta e irredutível. Muito mais profundo, muito mais complexo, denso e temerário que Cervantes... Como um historiador reagiria a tal afirmação? 
Como sustentá-la em tempos tão frementes quanto os do século XX? Mais do que um reescritor do Quixote-livro, porém, Menard é um leitor; um leitor que, da mesma maneira que o Quixote-personagem, acredita pia e apaixonadamente no que lê e, com o comboio de corda a lhe entreter a razão, tenta transpor o texto para a vida, e para o presente (Borges, 1974, p. 444-450).

Voltemos ao centro da questão: antes de sermos historiadores, pesquisadores, ficcionistas ou críticos, somos leitores, prioritariamente leitores; logo, precisamos reconhecer a instabilidade da nossa posição, a distância que mantemos (a despeito ou de acordo com a vontade de cada um) em relação ao texto com que nos defrontamos e ao que ele narra, em relação às verdades possíveis que cada texto nos oferece. Todo leitor enfrenta esse dilema, mas também é preciso diferenciar a variada atitude que esse leitor assume face aos diversos tipos de narrativa que frequenta. E esse é o momento de relembrar que as duas narrativas que aqui nos interessam, a historiográfica e a literária, têm compromissos distintos. Como Hayden White (1994, p. 137) enfatiza - defensivamente, diga-se de passagem - em Trópicos do discurso, a percepção de Aristóteles continua válida: diversamente do ficcionista, o historiador é regulado pelo que aconteceu. O compromisso do ficcionista é com a imaginação: ele pode inventar uma versão alucinada da vida nos engenhos, da Revolta Praieira ou da Guerra do Paraguai, pode criar uma trama incrivelmente rocambolesca sobre o suicídio de Vargas, sobre a trajetória de Xica da Silva, sobre o assassinato de Kennedy ou sobre a ditadura civil-militar brasileira. Já o compromisso do texto historiográfico é com uma verdade — que não é absoluta, plena ou pura, mas é a verdade possível, que podemos adjetivar ou metaforizar de muitas maneiras: "verdade relativa", "verdade provisória", "verdade comunicativa", "verdade tangível", "linha do horizonte". Ao leitor cabe reconhecer esses códigos e distintos compromissos e trabalhar dentro da lógica e da dinâmica da escritura que eles orientam. Mesmo porque o leitor não é submisso aos protocolos de leitura que o texto tenta lhe impor; ele não é, repitamos, um personagem passivo - Eco já sugeriu, cinco décadas atrás, que toda obra tende a ser "aberta" ou "móvel", e os fragmentos citados de Pessoa, Calvino ou do próprio Eco reiteram: o leitor prossegue o texto, o recria, reorienta seus elementos; lê a dor que bem entende, sempre distinta da sentida ou escrita pelo poeta. O leitor tampouco é estático: a cada momento, lemos de uma determinada forma e a partir de uma posição diferente (Eco, 1968). Jamais lemos só um texto: ao lê-lo, percorremos, na expressão feliz de Reinhart Koselleck (2014), "múltiplos estratos do tempo", estabelecemos contínuas relações, diretas ou indiretas, do texto que estamos lendo com outros textos que já lemos, de que ouvimos falar, ou com situações e experiências que vivemos, num processo que inclui partes conscientes e partes inconscientes.

Diante de tamanhas variações no trabalho de leitura, como um historiador pode aproximar-se do texto ficcional? Que riscos é importante evitar ou contornar? Na encruzilhada da 
história com a ficção, como ler o passado, tratar a verdade, vislumbrar o momento em que ela relampeja, perscrutar seu itinerário, penetrar surdamente no seu reino? É curioso notar que o mesmo historiador que é capaz de questionar à exaustão um documento, sondar incontáveis elementos ligados ao tempo de sua produção, às circunstâncias e aos mecanismos dessa produção; o mesmo historiador que é capaz de ler o que o documento diz e o que ele silencia e extrair, dessa relação complexa, traços que o ajudem a compreender uma experiência vivida anos, décadas ou séculos antes; o mesmo historiador que jamais acredita cegamente no que o documento afirma textualmente, pois esse mesmo historiador, diante de um texto ficcional, às vezes esquece de mobilizar todo seu aparato analítico e interpretativo, logo crítico, e age algo ingenuamente, buscando, na literatura, informações e revelações sobre o autor ou sobre o período em que se desenrola a trama ficcional. Como evitar tal perigo? E, aqui, ultrapassada a questão da leitura, passamos à segunda questão: a da representação do real na escrita (especialmente na escrita de ficção).

III.

Em primeiro lugar, é bom nos acautelarmos diante de certas metáforas enganosas: por exemplo, a de que o texto historiográfico ou literário "reflita" ou "espelhe" o "contexto" vivido por seu autor ou em que a história se desenvolve.

Também tomemos cuidado com a suposição de que o texto ficcional necessariamente revele as posições e opiniões pessoais — políticas, estéticas, ideológicas, morais etc. - do autor. Pode até ocorrer, mas para que tal hipótese seja confirmada dependemos, entre outros fatores, de uma identificação plena entre autor e narrador, o que nem numa autobiografia ou em diários pode ser assegurado; e aqui nos deparamos com uma diferença categórica em relação ao texto historiográfico, que tende a expor com muito mais vigor, e inevitavelmente, o posicionamento do historiador que o escreveu.

As metáforas "refletir" e "espelhar", por sua vez, sugerem que a razão, a "luz", nos assegura acesso à realidade, pois só há reflexo e espelhamento se houver luminosidade. As metáforas do "reflexo" e do "espelho" também nos levam a acreditar que possamos ultrapassar plenamente as mediações e as refrações, os desvios da luz, e enxergar exatamente o que ocorreu num dado tempo e lugar; elas nos levam a acreditar que o texto oferece, sem mistificações, a "dor sentida" por todo poeta.

Há, ainda, outro perigo: a que aludimos quando falamos em "contexto"? Se a verdade do historiador não é pura, absoluta ou definitiva, "contexto" não pode ser a experiência diretamente vivida, a realidade incontornável, a dor verdadeiramente sentida. Se nem o "contexto" que vivemos no presente é captável na sua totalidade, como controlar o passado que, 
como lembrou David Lowenthal (1985, p. XV-XVI), "está em toda parte", mas é "uma terra estrangeira"? Seja para compreendermos o presente, seja para compreendermos o passado - e guardadas as óbvias diferenças do esforço e do diverso trabalho de representação de cada temporalidade presente no texto e nos seus objetos - construímos representações do vivido que se pretendem abrangentes, capazes de reunir suficientes elementos e de compor uma noção de conjunto. Ou seja, o "contexto" também é, ele próprio, construído no texto historiográfico, literário, sociológico etc. Não pode, portanto, operar como garantia de verdade por trás do enredo ficcional, nem atuar como balizador da precisão da representação imaginativa. Da mesma maneira, não "reflete" ou "espelha" o que foi vivido, independentemente do compromisso que o texto ostente. O texto dialoga (e o leitor incorpora-se a esse diálogo e o desenvolve) com o passado e o representa conforme suas convenções, enquanto o real continua apenas um retrato na parede, e as dores vividas, expressas e lidas prosseguem paralelas.

O trabalho de ficção, por seu lado, é singular, pois ele, por princípio, dedica-se a estetizar o real. Stendhal, num texto de 1822, inclusive ironizou a metáfora do espelho de forma divertida, reorientando-a, e comparou a ficção a um espelho que se move ao longo de uma estrada: "um espelho que alguém carrega, e que reflete a realidade comezinha a cercar esse alguém, uma realidade muito específica que a esse indivíduo acomete" (Stendhal, 1980, p. 34). Peter Gay (2010, p. 18), em obra bastante posterior, completou: é um espelho que se move ao longo de uma rodovia e que, sobretudo, distorce.

O que estava em jogo para Stendhal e para Gay, no caso, era o romance do século XIX que, com seu evidente pendor para o realismo, se empenhou, como lembra Julián Fuks (2016, p. 13), em

assimilar o real (...), chegar ao âmago da realidade através de sua representação mais expressiva ou exata. Ir além de sua imitação, ir além de uma mera cópia: tornar-se a inscrição pura, imediata, imanente do mundo, e mesmo superior a ele, por revelar a estrutura que nele se esconde.

Não por acaso, como já notou Ian Watt (1996), a ascensão do romance, a partir do século XVIII, correspondeu à ascensão do realismo e gerou projetos ambiciosos, como os de Balzac ou Tolstói, que equipararam a ficção a uma "história privada das nações" e pretenderam ser historiadores de seu século - e não vamos discutir, aqui, o que entendiam por historiador - , capaz de "expor" o funcionamento real e inteiro da sociedade e, mais ainda, interferir na realidade. Seus romances eram recheados, lembra Franco Moretti (2009, p. 838), de objetos concretos, que compunham os indícios de realidade, ampliavam o "efeito de real" (Barthes, 1984, p. 184-187) e asseguravam o vínculo, digamos, da "dor escrita" com a "dor sentida". Eles assumiam e reproduziam uma dimensão "utilitária" da ficção (a mesma 
que Sartre, um século depois, reiteraria, e que Adorno, em nome da autonomia da arte, rejeitaria): o romance deveria ser um instrumento cirúrgico capaz de dissecar a realidade e expor a experiência. O projeto, porém, era limitado, destaca Auerbach: "o realismo moderno sério não pode representar o homem senão engastado numa realidade político-socio- econômica concreta e em constante evolução", para em seguida observar que "o realismo precisa ser adjetivado" - nenhum realismo é isento de caracterização que o especifique e elimine o sentido de plenitude, nenhuma obra se refere a um "contexto": ela remete a uma experiência histórica ampla e pouco ou nada apreensível na sua completude (Auerbach, 1971, p. 480, 475-476). Ou seja, "contexto" - palavra que nós, historiadores, tanto empregamos - indica um momento específico, um quadro específico, e, mais significativo e limitador, deriva de posição e perspectiva particulares: é expressão, portanto, que contém as marcas do subjetivo e do efêmero, é construção histórica e textual (LaCapra, 1985). Ou ainda, como ressaltou Flaubert (2005, p. 110), ainda no século XIX, ao apontar a agonia do romance como forma, o que se pretendia universal era, na verdade, uma sensibilidade singular, criada num tempo e por um olhar, tempo e olhar específicos.

Para os objetivos deste texto - pensar a relação entre ficção e história e o trabalho com a literatura dentro da historiografia - é importante ultrapassar a marca do grande romance do século XIX e evitar a associação direta e, embora atraente, impertinente, entre ficção e realidade. O problema, porém, é: a que ponto chegamos? Sem espelhamento ou reflexo, e com a ideia de contexto problematizada, teríamos atestado a impossibilidade do recurso à ficção por historiadores? Certamente não. A aproximação entre ficção e história reafirma, inclusive através da percepção das distintas fundações e do diverso compromisso das duas narrativas, mais um caminho possível e instigante para a historiografia, daí a necessidade de entender a relação e o diálogo entre ficção e história de uma forma mais mediada, mais cheia de limites, de tensões e de possibilidades, reafirmando a sentença de Reinhart Koselleck (1997, p. 228) de que "a teoria da história é sobretudo a teoria das condições de possibilidade da história".

IV.

Sartre, num livro talvez tão grandioso quanto a obra que estuda, observou que, apesar de Flaubert criticar tão duramente a utopia realística do grande romance histórico do século XIX, ele não se mantinha totalmente alheio ao mundo que o cercava; ele também se esforçava por "compreender o mundo ao seu redor, em captá-lo pela minúcia da linguagem, 
em alcançar sua inalcançável verdade" (Sartre, 1971, p.114). "Alcançar o inalcançável" é paradoxal apenas na aparência. Para Sartre, a especificidade de Flaubert estava no fato de que ele operava pela exceção e, a partir dela, atingia o panorama geral. Flaubert falava de personagens algo singulares, de irrealidades que continham e podiam insinuar traços sutis do tempo para concluir que, no detalhe e no alusivo, às vezes arduamente perceptível, pode estar o mundo.

Jacques Rancière também revisita Flaubert para investigar a imensa atenção de sua prosa ao que pode parecer insignificante, banal ou frívolo - numa espécie de distorção da escala de importância dos objetos - , mas que age decisivamente para desenredar o hieróglifo do passado (Rancière, 2017, p. 36). Assim como David Lowenthal (1996), em seu estudo instigante sobre as relíquias, aponta para uma discussão semelhante e oferece uma nova estratégia de pensar - e possuir - o passado a partir de fragmentos frágeis e dissociados, mas sinais discretos, capazes de proporcionar consciência do passado. O mesmo Lowenthal (1985, p. 259) já havia observado, uma década antes, que "como o passado parece afastar-se de nós, procuramos reevocá-lo novamente multiplicando a parafernália sobre ele - lembranças, mementos, romances históricos, velhas fotos".

Os recursos e procedimentos dos historiadores na investigação do passado encontram claro paralelo na forma como críticos literários e ficcionistas caracterizam seu ofício e seus esforços. Philip Roth (2016, p. 13), por exemplo, justifica sua autobiografia (em carta ao personagem central de vários de seus romances) e delineia os contornos irregulares da verdade ao afirmar que ficção "transfigura", é "máscara", "disfarce", "distorção" e "mentira"; que a ficção pretende "chicotear os fatos para tornar a vida real mais instigante. Remoer a experiência, embelezar a experiência, rearrumar e expandir a experiência numa espécie de mitologia".

A mesma associação entre ficção e mentira, e sua importância para a compreensão do passado, também aparece num trecho vaidoso e enfático de Mario Vargas Llosa:

Os homens não vivem só de verdades; também sentem falta das mentiras: das que inventam livremente, não das que lhes são impostas; das que se apresentam como o que são, não das contrabandeadas sob a roupagem da história. (...) Dessa liberdade [de mentir] nascem outras. Esses refúgios privados, as verdades subjetivas da literatura, conferem à verdade histórica, que é seu complemento, uma existência possível e uma função própria: resgatar uma parte importante - e apenas uma parte - da nossa memória: aquelas grandezas e misérias que dividimos com os outros na nossa condição de seres gregários. Essa verdade histórica é indispensável e insubstituível para que

2 Ver também: Sartre, 1960 (que incorpora o ensaio "Questions de méthode", originalmente publicado em 1957), livro de forte impacto sobre historiadores brasileiros como Fernando Novais e Ciro Flammarion Sant’Anna Cardoso. 
saibamos o que fomos e, talvez, o que seremos como coletividade humana. Mas o que somos como indivíduos e o que quisemos ser e não o pudemos ser de verdade, e só conseguimos sê-lo, portanto, ao fantasiarmos e inventarmos - nossa história secreta -, apenas a literatura sabe contar (Vargas Llosa, 2002, p. 29-30).

É possível prolongar a discussão sobre a "mentira da literatura" e a "verdade da história" - e ao mesmo tempo atenuar o privilégio que Vargas Llosa confere à ficção - lembrando a observação de Antonio Tabucchi (2003, p. 12): "a mentira tem, de qualquer forma, certa utilidade: serve para definir os confins da verdade”. Resta-nos, no entanto, a questão: como relacionar todos esses enganos, essas mentiras ficcionais, à verdade (comunicativa, provisória, tangível) que pretende a história? Georges Didi-Huberman (2012) — historiador da arte que insiste que não deve haver privilégio da imagem sobre a linguagem — aproxima a literatura de ficção das artes visuais e reconhece em ambas a possibilidade de não estabelecer uma relação conformista com o passado e de lê-lo de maneira criativa para, de forma benjaminiana, aumentar a visibilidade dos tempos, tornar possível ler o tempo da história: ler o que nunca foi escrito, seja a partir dos detalhes, seja por meio da combinação criteriosa entre verdades e mentiras.

Também na crítica literária o debate acerca da força da leitura e da especulação sobre a experiência vivida ganhou força, conforme atesta Julián Fuks:

Como estetização do real, cada romance devolve ao mundo não apenas sua imagem distorcida, mas também uma especulação empírica sobre o real e sobre a escrita: uma específica proposta estética em que escrita e real não são coisas diversas (Fuks, 2016, p. 12).

Ou seja, a literatura pode ser, sim, um sismógrafo acurado, inclusive para a história: graças à sua liberdade criativa e ao amplo aparato de recursos estéticos e de linguagem, ela pode perceber com agilidade o que outras narrativas demoram mais a notar. Resta, entretanto, que jamais nós, historiadores-leitores, ignoremos a dimensão estética da ficção; que jamais desconsideremos o trabalho em si da escrita: se algo a ficção tem a nos dizer sobre o passado, isso deve ser buscado menos numa suposta revelação imediata do "contexto", menos nas informações "históricas" que o texto literário nos oferece - e que, evidentemente, não são dignas de confiança plena - e mais em elementos discretos ou associados ao trabalho em si de construção de texto, ao contexto cognitivo - e aqui o adjetivo reinventa o substantivo - que o permitiu.

A ficção, afinal, persiste sendo o que Eco descreve como um "bosque", em meio ao qual é preciso achar caminhos:

'Bosque' é uma metáfora para o texto narrativo. (...) Há bosques como Dublin, onde em lugar de Chapeuzinho Vermelho podemos encontrar Molly Bloom, e bosques como 
Casablanca, no qual podemos encontrar Ilsa Lund ou Rick Blaine. Usando uma metáfora criada por Jorge Luis Borges (...), um bosque é um jardim de caminhos que se bifurcam. Mesmo quando não existem num bosque trilhas bem definidas, todos podem traçar sua própria trilha, decidindo ir para a esquerda ou para a direita de determinada árvore e, a cada árvore que encontrar, optando por esta ou aquela direção. Num texto narrativo, o leitor é obrigado a optar o tempo todo (Eco, 1994, p. 12).

Se Jacques Le Goff pôde afirmar mais de uma vez que decidiu ser historiador após ler Ivanhoé, de Walter Scott, ${ }^{3}$ Carlo Ginzburg, em entrevista a Maria Lúcia Pallares-Burke, nos dá outra pista:

Anos atrás, fui entrevistado por meu amigo Adriano Sofri, que me perguntou sobre o conselho que daria aos jovens historiadores. Leiam romances, respondi. Naquela época esse me parecia o modo de fazer que desenvolvessem o que chamo de imaginação moral, ou seja, aquilo que nos permite fazer conjecturas sobre os seres humanos, algo que está envolvido em todas as interações sociais. Ora, essas conjecturas se baseiam, no meu entender, no que aprendemos sobre os seres humanos, e muito disso depende do que lemos, desde contos de fadas a romances contemporâneos. A leitura nos descortina toda uma gama de possibilidades humanas e, se tivermos tido a sorte de ler, por exemplo, Crime e castigo de Dostoievski, a figura de Raskólhnikov estará sempre afetando nosso modo de encarar a humanidade. Hoje, no entanto, hesitaria em dar tal conselho, pois detestaria ser confundido indevidamente com aqueles que alimentam a moda atual de se borrar a distinção entre história e ficção. Evidentemente, ainda acredito na leitura de romances, mas acrescento o seguinte alerta: leiam romances, mas saibam que história e ficção são gêneros distintos que apresentam desafios um ao outro (Pallares-Burke, 2000, p. 296-297).

Quando deu essa entrevista, Ginzburg continuava envolto em sua interminável polêmica com Hayden White, mas, mais importante do que isso, acabara de escrever Olhos de madeira, um livro dedicado a pensar a "distância" — inclusive a proporcionada pelos anacronismos antes mencionados -, ou o "estranhamento" que, desde o título, capta a perplexidade de Geppetto sob os olhos ainda sem vida, mas já inquietantes, posto que estranhos, de Pinocchio. Ginzburg se pergunta: qual é o sentido do estranhamento? E, em linha geral, responde que se pode recorrer ao distante para compreender o que é próximo, para dizer coisas que de outra forma não seriam ditas, que há um lugar para o estranhamento, e esse é o lugar dos "estrangeiros" (ou "estranhos"), dos marginais (tanto na acepção inicial: os que estão fora do centro, à margem; quanto na acepção assumida: os que ameaçam

${ }^{3}$ Ver, por exemplo: Pierre Nora (1987). 
e desafiam), aqueles que podem, de fora, explicar o que os que estão dentro não conseguem ver e entender. Esse estranhamento não apenas é técnica (como foi para os formalistas russos), mas uma forma de compreensão, uma estratégia compreensiva, ou seja, é interpretação: "No interior dessa tradição, o estranhamento é um meio para superar as aparências e alcançar uma compreensão mais profunda da realidade" (Ginzburg, 2001, p. 36). ${ }^{4}$

Face à história, a ficção é inevitavelmente uma estranha e seu olhar é marginal: ela "pinta ao revés" - metáfora que Ginzburg colhe de Proust (a pintura de Elstir, amigo do narrador de Em busca do tempo perdido) - e esse é seu jeito de criar, para si, uma condição estranha, que permita enxergar as coisas por um prisma marginal:

Elstir tinha se esforçado, diz Proust, 'para expor as coisas não como ele sabia que eram...', uma observação ligada à sua costumeira depreciação da inteligência, à sua insistência quanto ao primado da experiência vivida sobre as fórmulas pré-constituídas, os hábitos rígidos, o 'saber' (Ginzburg, 2001, p. 38).

Em outros termos, Elstir — e, depois dele, Proust, e, depois dele, Ginzburg, e talvez nós - reconhece que "o comboio de corda que se chama o coração" continua "a entreter a razão", e é preciso considerá-lo. A "pintura ao revés" tem, por isso, sentido essencialmente cognitivo: pinta-se fora da expectativa para entender o que se passa; recusa-se o mimetismo na representação, confirma-se a rejeição do realismo "não adjetivado" do grande romance histórico do século XIX, altera-se arbitrariamente a representação para provocar o estranhamento e atingir uma perspectiva antes insuspeita, para "alcançar o inalcançável":

Parece-me que o estranhamento é um antídoto eficaz contra um risco a que todos nós estamos expostos: o de banalizar a realidade (inclusive nós mesmos) (...) Proust (...) queria sugerir que tanto os historiadores como os romancistas (ou os pintores) estão irmanados num fim cognitivo (Ginzburg, 2001, p. 41).

Ao salientar as implicações cognitivas do estranhamento, Ginzburg recorre a Proust para descartar a tradição de naturalização da história, o reconhecimento de "contextos" estáticos, e para celebrar o trabalho interpretativo, que, muitas vezes, deriva ou se opera mais profundamente a partir de uma mentira, a da ficção, ou de um fingimento, do que de uma suposta verdade, construída social e textualmente. Na citada entrevista a Maria Lúcia Pallares-Burke (2000, p. 297), Ginzburg associa distância, estranhamento, inquietude à

${ }^{4}$ Evidentemente, a defesa de uma posição indireta de observação do passado não é consensual, sobretudo entre historiadores que privilegiam o engajamento direto dos historiadores e da historiografia Josep Fontana (1998), por exemplo, a considera "pouco eficaz". Eric Hobsbawm (1998), por sua vez, rejeita a falta de engajamento que ela implica. 
"imaginação moral", que ele traduz como "capacidade de fazer conjecturas sobre o ser humano". Assim atualiza, seguindo uma trilha já percorrida por Eliot e Faulkner, a noção que surgiu com Edmund Burke, no estertor do século XVIII: para Burke, "imaginação moral" era, cito Russell Kirk (201l, p. 140), a "capacidade de percepção ética que transpõe as barreiras da experiência privada e dos acontecimentos do momento (...) especialmente (...) as formas dessa capacidade praticadas na poesia e na arte". "Imaginação moral" como a reintegração do particular no todo - um retorno ao mundo, que então se transformara como a tensão entre razão e irrazão, entre a "imaginação idílica" e a "imaginação diabólica".

Trata-se, portanto, de uma imaginação moral que indica um lugar de leitura e um esforço de compreensão mais profunda da subjetividade contemporânea; que encoraja a especulação e acentua o senso imaginativo acerca dos sujeitos históricos. Essa imaginação moral, já enfatizaram Lionel Trilling e Gertrude Himmelfarb, jamais se confunde com qualquer tipo de moralismo, nem com concepções absolutas ou religiosas, e sim com a imaginação acerca das possibilidades, da variedade e da complexidade de todo trabalho de representação e de todo sujeito (Trilling, 2015; Himmelfarb, 2012). Não por acaso, Ricardo Piglia (2017, p. 354) constata: "de todos os signos da linguagem, o Eu é o mais difícil de controlar, o último que a criança adquire e o primeiro que o afásico perde. A meio caminho entre ambos, o escritor adquiriu o hábito de falar de si mesmo como se falasse do outro". E, no segundo volume de Os diários de Emilio Renzi - obra de um autor que gostava de dizer que se graduou em história para melhor compreender a ficção - , Piglia (2016, p. 69) recorre a mesma metáfora do revés para relacionar experiência histórica e literatura: "Nunca me preocupou a ideia de que a literatura nos afastasse da experiência, porque, para mim, as coisas acontecem ao revés: a literatura constrói a experiência”(Piglia, 2016, p. 69). ${ }^{5}$ Piglia valoriza a necessidade de, por meio da ficção, pensar o passado para compreender o presente, teoriza sobre a história para alcançar, novamente nos termos de Koselleck (1997, p. 228), uma "teoria das possibilidades da história”, age para sobreviver no presente e acreditar em algum futuro.

Ginzburg, ainda na entrevista a Pallares-Burke, reforça justamente essa capacidade de restaurar a experiência por meio de sua ressignificação e a partir do diálogo entre olhares e perspectivas diversas, da percepção aguda do outro, da proliferação de sujeitos e da transição do indivíduo, ou do específico, para o coletivo e para o plural. Dessa forma, ao aludir ao confronto categórico entre o olhar centrado e o olhar excêntrico, alarga a compreensão do espaço da ficção na história.

5 Tal afirmação insinua, nas entrelinhas, o célebre "The dry salvages", de T.S. Eliot, que o autor argentino usou como epígrafe de seu romance mais vertiginoso, Respiração artificial, escrito durante o regime militar argentino - de 1976 a 1983 - e que, já no título, sugere a necessidade de repensar o passado para compreender o presente. 
Rancière, no mesmo O fio perdido, avança, destacando a dimensão política do ato de ler e configurando uma "política da ficção":

Eu posicionarei, então, a política da ficção não ao lado do que ela representa, mas ao lado do que ela realiza: as sinalizações que ela constrói, as populações que ela convoca, as relações de inclusão ou exclusão que ela institui, as fronteiras que ela traça ou apaga entre a percepção e a ação, entre os estados de coisas e os movimentos do pensamento; as relações que ela estabelece ou suspende entre as situações e as significações, entre as coexistências ou sucessões temporais e as cadeias de causalidade (Rancière, 2017, p. 13-14).

Ao enfatizar as "realizações" da ficção, Rancière cria, assim, uma ligação — o "fio" uma zona de passagem, ou de transição, entre a ficção e a história, inclusive porque, como notou Lowenthal,

O que hoje conhecemos como ‘o passado' não é o que alguém experimentou como ‘o presente’. Em alguns aspectos, nós conhecemos esse passado melhor do que aqueles que o viveram. (...) Tanto a estrutura quanto o conteúdo da ficção contemporânea reorganizam substancialmente o passado (Lowenthal, 1985, p. 191, 227).

No entanto, e nunca é desnecessário reiterar, as "formas da ficção" dialogam com as da história e, apesar das muitas aproximações possíveis - por exemplo, por White, em seu esforço de identificar bases discursivas e efeitos comuns à história e à ficção (White, 1994, p. 101) - delas se distinguem: não são idênticas, não respeitam os mesmos compromissos e não desembocam nos mesmos resultados. Historiadores e ficcionistas, prossegue Lowenthal, tampouco devem enganar-se quanto às possibilidades e aos limites de sua representação do vivido:

A diferença entre história e ficção está mais no objetivo do que no conteúdo. Independentemente dos mecanismos retóricos de que o historiador disponha, os objetivos de seu ofício vedam-lhe inventar ou excluir algo que afete suas conclusões; ao se definir historiador, e história a seu ofício, ele opta por que ela seja julgada pela precisão, consistência interna e congruência com os registros remanescentes. E, para tornar sua narrativa mais inteligível, ele não ousa inventar um personagem, atribuir traços desconhecidos ou incidentais aos personagens verdadeiros ou ignorar aquelas marcas incompatíveis, porque não poderia esconder tais invenções de quem tem acesso aos registros públicos, e nem sustentá-las, se expostas (Lowenthal, 1985, p. 229).

As constatações de Lowenthal reforçam a dimensão ambígua que une história e ficção e mostram que ninguém poderia afirmar, a propósito da história, aquilo que James Wood (2017, posição 117-120) constata: "O real, na ficção, é sempre uma questão de crença”. O real, 
na história, é construção não livremente imaginativa: nele, a experiência do passado reaparece restaurada e ressignificada. Mesmo que sua composição resulte de inevitáveis anacronismos, ela revela a conjugação de perspectivas variadas e o respeito ao compromisso com o manejo adequado da documentação. O leitor - aquele criador de novas narrativas que aparecia no início desse texto - "acredita" no relato histórico porque assume previamente a existência de tais compromissos. Em outras palavras, história não é ficção. No entanto, ficcionistas e historiadores, quando tecem seus longos bordados narrativos, compartilham rituais assemelhados de reconhecimento e estranhamento, problematizam a verdade do que veem e do que escrevem, deslocam-se em meio às sombras de temporalidades passadas e presentes, frequentam teorias e metodologias dissonantes, buscam posição adequada para representar - distanciam-se para mostrar (Didi-Huberman, 2000).

Retornemos a Proust e a Elstir para concluir: a ficção pode, sim, representar a história "ao revés", ampliando, para nós, leitores-historiadores, a dimensão do trabalho crítico, promovendo a "imaginação moral". E a reflexão histórica pode permitir-se recorrer a procedimentos narrativos que costumamos encontrar com mais frequência na ficção: por exemplo, o que moveu este artigo desde o princípio e que talvez derive de uma conhecida declaração de Borges, em que ele afirma que aquele que escreve no século XX (ou depois) deve admitir que a originalidade plena é uma quimera inadequadamente anacrônica; que todo escritor tem de postular a condição de "amanuense do engenho alheio", de "memória individual do coletivo" (apud Ferrari, 1986, p. 84-85), de alguém que se propõe a (re)articular o que já foi dito e escrito, a produzir uma combinação nova, capaz de gerar significados também novos e, claro, jamais definitivos - narrativas provisórias, à espera de outra invenção do passado.

No emocionante final do volume l de Os diários de Emilio Renzi - livro repleto de verdades e mentiras, acessíveis aos mais diversos leitores e todo escrito no fio da lâmina entre a ficção, a memória e a história - , Ricardo Piglia expõe um Emilio Renzi - seu personagem, seu alterego, seu duplo - ainda elíptico, mesmo em meio à doença paralisante que mataria tragicamente o próprio Piglia:

[Renzi] retomou a oração que tinha deixado em suspenso, suspensa, como um trapezista que espera, alucinado, o sinal de seu parceiro para então se arremessar no ar e sem rede num duplo salto mortal que culmina quando apanha as mãos de seu ajudante que o espera, suspenso no alto, e se segura nele, como se diz, no ar. Isso que é narrar, disse em seguida, arremessar-se no vazio e acreditar que algum leitor vai segurá-lo no ar (Piglia, 2017, p. 363).

Em meio ao bosque, ao revés, suspenso no ar. Pela ficção, nós, historiadores, oferecemos a mão a esse trapezista. Suspensos e seguros no ar com ele, revisitamos o passado e, também fingidores, escrevemos história. 
Se a ficção de fato for um sismógrafo acurado e instigar a imaginação e a capacidade de ampliar a consciência do passado, de si e do outro, de explorar os estratos plurais do tempo, lê-la e estudá-la em diálogo com a história nos ajuda a concordar com Paulinho da Viola e afirmar que, "quando penso no futuro, não esqueço meu passado".

\section{Referências}

AUERBACH, Erich. Mimesis: a representação da realidade na literatura ocidental. São Paulo: Perspectiva, 1971.

BARTHES, Roland. Le bruissement de la langue: essais critiques IV. Paris: Seuil, 1984.

BLOCH, Marc. Apologia da história ou o ofício do historiador. Rio de Janeiro: Jorge Zahar, 1994.

BORGES, Jorge Luis. Pierre Menard, autor del Quijote. In: BORGES, Jorge Luis. Obras completas. Buenos Aires: Emecé, 1974, p. 444-450.

BRAUDEL, Fernand. Escritos sobre a história. São Paulo: Perspectiva, 1978.

CALVINO, Italo. Saggi. Milão: Mondadori, 1995.

DIDI-HUBERMAN, Georges. Devant le temps. Paris: Les Éditions de Minuit, 2000.

DIDI-HUBERMAN, Georges. L'oil de l'histoire. v. 4: Peuples exposés, peuples figurants. Paris: Les Éditions de Minuit, 2012.

DIDI-HUBERMAN, Georges. A imagem sobrevivente: história da arte e tempo dos fantasmas segundo Aby Warburg. Rio de Janeiro: Contraponto, 2015.

ECO, Umberto. Obra aberta: forma e indeterminação nas poéticas contemporâneas. São Paulo: Perspectiva, 1968.

ECO, Umberto. Seis passeios pelos bosques da ficção. São Paulo: Companhia das Letras, 1994.

ECO, Umberto. Lector in fabula: a cooperação interpretativa nos textos narrativos. São Paulo: Perspectiva, 2011.

FERRARI, Osvaldo (Org.). Borges em diálogo. Rio de Janeiro: Rocco, 1986.

FEBVRE, Lucien. Combats pour l'histoire. Paris: Armand Colin, 1953.

FEBVRE, Lucien. A história da incredulidade no século XVI: a religião de Rabelais. São Paulo: Companhia das Letras, 2009.

FLAUBERT, Gustave. Cartas exemplares. Rio de Janeiro: Imago, 2005.

FONTANA, Josep. História: análise do passado e projeto social. Bauru: Edusc, 1998.

FUKS, Julián. História abstrata do romance. Tese (Doutorado em Teoria Literária e Literatura Comparada), Universidade de São Paulo. São Paulo, 2016.

GADAMER, Hans-Georg. O problema da consciência histórica. Rio de Janeiro: Editora FGV, 2001.

GAY, Peter. Represálias selvagens: realidade e ficção na literatura de Charles Dickens, Gustave Flaubert e Thomas Mann. São Paulo: Companhia das Letras, 2010.

GINZBURG, Carlo. Olhos de madeira: nove reflexões sobre a distância. São Paulo: Companhia das Letras, 2001.

HIMMELFARB, Gertrud. Moral imagination: from Adam Smith to Lionel Trilling. Nova York: Rowman \& Littlefield, 2012.

HOBSBAWM, Eric. Sobre história. São Paulo: Companhia das Letras, 1998.

KIRK, Russell. A era de T.S. Eliot: a imaginação moral do século XX. São Paulo: É Realizações, 2011.

KOSELLECK, Reinhart. L'expérience de l'histoire. Paris: Gallimard, 1997.

KOSELLECK, Reinhart. Estratos do tempo: estudos sobre história. Rio de Janeiro: Contraponto, 2014.

LACAPRA, Dominick. History and criticism. Ithaca: Cornell University Press, 1985. 
LEFRANC, Abel. La vie quotidienne au temps de la Renaissance. Paris: Hachette, 1938.

LORAUX, Nicole. Éloge de l'anachronisme em histoire. Espaces Temps (Paris). n. 87-88, p. 127-139, 2005.

LOWENTHAL, David. The past is a foreign country. Cambridge: Cambridge University Press, 1985.

LOWENTHAL, David. Possessed by the past: the heritage crusade and the spoils of history. New York: Free Press, 1996.

MORETTI, Franco. A cultura do romance. São Paulo: Cosac Naify, 2009.

NORA, Pierre (Org.). Essais d'ego-histoire. Paris: Gallimard, 1987.

PALLARES-BURKE, Maria Lúcia. As muitas faces da história. São Paulo: Editora da Unesp, 2000.

PESSOA, Fernando. Obra poética. Rio de Janeiro: Aguilar, 1960.

PIGLIA, Ricardo. Los diarios de Emilio Renzi. v. 2: Los años felices. Barcelona: Anagrama, 2016.

PIGLIA, Ricardo. Os diários de Emilio Renzi. v. 1: Anos de formação. São Paulo: Todavia, 2017.

PREMAT, Julio. Non nova sed nove: inactualidades, anacronismos, resistencias. Roma: Quodlibet, 2018.

RANCIÈRE, Jacques. Le concept d'anachronisme et la vérité de l'historien. L'Inactuel (Paris). n. 6, p. 5368, 1996.
RANCIÈRE, Jacques. O fio perdido: ensaios sobre a ficção moderna. São Paulo: Martins Fontes, 2017.

RICCEUR, Paul. História everdade. Rio de Janeiro: Forense-Universitária, 1968.

ROTH, Philip. Os fatos. São Paulo: Companhia das Letras, 2016.

SARTRE, Jean-Paul. Critique de la raison dialectique. Paris: Gallimard, 1960.

SARTRE, Jean-Paul. L'idiot de la famille. v. 1. Paris: Gallimard, 1971.

STHENDAL (Henri-Marie Beyle). De l'amour. Paris: Gallimard, 1980.

TABUCCHI, Antonio. Autobiografie altrui. Milão: Feltrinelli, 2003.

TRILLING, Lionel. A imaginação liberal: ensaios sobre a relação entre literatura e sociedade. São Paulo: É Realizações, 2015.

VARGAS LLOSA, Mario. La verdad de las mentiras. Buenos Aires: Alfaguara, 2002.

WATT, Ian. A ascensão do romance. São Paulo: Companhia das Letras, 1996.

WHITE, Hayden. Trópicos do discurso: ensaios sobre a crítica da cultura. São Paulo: Edusp, 1994.

WOOD, James. A coisa mais próxima da vida. [Livro eletrônico]. São Paulo: Sesi, 2017. 